6 Tanigaki, N., Nakamura, K., Natori, T., Kreiter, V. P. \& Pressman, D. Transplantation i8, 74-78 (1974).

7 Sanderson, A R. \& Welsh, K. I. Transplant. Proc. 5, 471-475 (1973).

8 Sanderson, A R. \& Welsh, K. I. Transplantation 16, 304-312 (1973).

"Metzgar, R. S. \& Miller, J. L. Transplantation 13, 467-471 (1972).

10 Farr, R. S. J. infect. Dis. 103, 239-251 (1958).

(1967), K. \& Rottländer, E. Cold Spring Harb. Symp. quant. Biol. 32, 547-555 (1967).

13 Mitchison, N. A. Cold Spring Harb. Symp. quant. Biol. 32, $431-440$ (1967)

13 Welsh, K. I. Burgos, H. \& Batchelor, J. R. Eur. J. Immun: (in the press).

5 Lake. P. \& Mitchison, N. A. Cold Spring Harb. Symp. quant. Biol. (in the press) o Nisbe1, N. W.. Simonsen, M. \& Zaleski. M.J. exp. Mets. 129, 459-467 (1969). 7 Sanderson A. B \& W. L. \& Nowell, P. C. J. exp. Med. 128, 1157-1181 (1968).

8 Peckerson, A. R. \& Weish, K. T. Transplant. Proc. 6, 163-167 (1974).

(9) Zink, A. B., Alter, B. J. \& Lindahl, K. F. Trunsplant. Rev. 29, 189-221 (1976).

\section{In a radiation chimaera, host H-2 antigens determine immune responsiveness of donor cytotoxic cells}

CELL membrane structures controlled by genes in the major histocompatibility complex ( $\mathrm{H}-2$ in mice) are involved in most immune interactions between $\mathrm{T}$ lymphocytes and other cells ${ }^{1}$. Cytotoxic T lymphocytes (CTL) immunised against viruses ${ }^{2}$, haptens ${ }^{3}$, minor histocompatibility antigens ${ }^{4}$ or tumour antigens ${ }^{5}$, are specific for self $\mathrm{H}-2$ antigens as well as for the foreign antigen. But CTL are not restricted to recognising antigens in combination with only self $\mathrm{H}-2$. $\mathrm{H}-2^{\text {d }}$ homozygous $\mathrm{CTL}$ which have matured in an irradiated $\mathrm{H}-2^{\mathrm{d}} / \mathrm{H}-2^{\mathrm{k}}$ host can respond to antigen plus $\mathrm{H}-2^{k}$ in addition to antigen plus $\mathrm{H}-2^{\text {d }}$ ( $\mathrm{refs} 6-8$ ). It is not known whether the $\mathrm{H}-2$ environment in which $\mathrm{T}$ cells mature influences their range of specificity, that is, whether CTL from a normal mouse can respond quantitatively as well to antigen plus foreign $\mathrm{H}-2$ as they do to antigen plus self $\mathrm{H}-2$. These experiments were designed to test this influence. The results suggest that host $\mathrm{H}-2$ antigens do exert an effect on the specificity of T-cell responses.

A single suspension of bone marrow cells from $F_{1}(B A L B / c \times$ BALB.B $)\left(F_{1}(C \times C . B), H \cdots 2^{d} / H-2^{b}\right)$ mice was used to reconstitute groups of lethally irradiated parental mice, $\mathrm{C}\left(\mathrm{H}-2^{\mathrm{d}}\right)\left(\left[\mathrm{F}_{1} \rightarrow \mathrm{C}\right]\right.$ chimaeras$)$ and $\mathrm{C} . \mathrm{B}\left(\mathrm{H}-2^{\mathrm{b}}\right)\left(\left[\mathrm{F}_{1} \rightarrow \mathrm{C} . \mathrm{B}\right] \mathrm{chim}-\right.$ aeras). Eight weeks later these chimaeric mice and normal $\mathrm{F}_{1}(\mathrm{C} \times \mathrm{C} . \mathrm{B})$ mice were primed against minor $\mathrm{H}$ antigens by injecting $8 \times 10^{6} \mathrm{~F}_{1}(\mathrm{BI} 0 \times \mathrm{BI} 0 . \mathrm{D} 2)\left(\mathrm{H}-2^{\mathrm{b}} / \mathrm{H}-2^{\mathrm{d}}\right)$ spleen cells. The $\mathrm{B} 10$ background offers more than 30 minor histocompatibility antigenic differences that can be recognised by BALB mice ${ }^{9.10}$. Some weeks later the primed spleen cells were boosted in culture with irradiated $F_{1}(B 10 \times B 10 . D 2)$ stimulator cells and assayed for cytotoxicity $5 \mathrm{~d}$ later.

Following this immunisation procedure, celis from normal $\mathrm{F}_{1}(\mathrm{C} \times \mathrm{C} . \mathrm{B})$ mice lysed $\mathrm{B} 10$ targets and $\mathrm{B} 10 . \mathrm{D} 2$ targets almost equally (Table 1). (The two activities are mediated by separate pools of $\mathrm{CTL}^{2-4}$ ) The chimaeras responded differently. In the same conditions of immunisation with $F_{1}(B 10 \times B 10 . D 2)$ cells, they responded preferentially to the minor antigens in association with the $\mathrm{H} 2$ antigens of the host. CTL from the $\left[F_{1} \rightarrow C\right]$ chimaeras killed B10.D2 targets better than B10 targets, whereas CTL from $\left[F_{1} \rightarrow\right.$ C.B] chimaeras lysed B10 targets better than B10.D2 targets (Table 1).

Spleen cells from five chimaeras were assayed for their content of host and donor cells at time of killing. Complement-mediated lysis with $\mathrm{H}-2^{\mathrm{b}}$ anti-H- $2^{\mathrm{d}}$ serum and with $\mathrm{H}-2^{\mathrm{d}}$ anti- $\mathrm{H}-2^{\mathrm{b}}$ serum indicated that in all cases at least $85 \%$ of the cells were of $F_{1}$ (donor) origin. The cytotoxic effector cells were also lysed with anti-H-2 serum and complement just before the ${ }^{51} \mathrm{Cr}$-release assay (Table $2)$. Here, the $\left[F_{1} \rightarrow C\right]$ chimaera cells lysed $B 10 . D 2$ targets ninefold more efficiently than they lysed $\mathrm{B} 10$ targets (data not shown). The killer cells were treated with antiserum plus complement, washed, and assayed for lysis of labelled B10.D2. Table 2 shows, most importantly, that BALB/c anti-C57BL/6 (anti-H-2 ${ }^{\text {b }}$ ) serum reduced the cytotoxic activity $86 \%$ compared with controls. This antiserum does not lyse BALB/c effector cells. Therefore, at least $86 \%$ of the CTL were of $F_{1}$ bone marrow origin.

These experiments show that $\mathrm{H} \cdot 2^{\mathrm{d}} / \mathrm{H}-2^{b}$ cytotoxic cells which mature in an irradiated $\mathrm{H}-2^{\mathrm{d}}$ host respond preferentially to antigens plus $\mathrm{H}-2^{\mathrm{d}}$, whereas $\mathrm{H}-2^{\mathrm{d}} / \mathrm{H}-2^{\mathrm{b}}$ cells which mature in an irradiated $\mathrm{H} \cdot 2^{\mathrm{b}}$ host respond preferentially to the same antigens in conjunction with $\mathrm{H}-2^{b}$ gene products. The experiments were designed to test the 1971 Jerne hypothesis ${ }^{14}$, or a modified version of $\mathrm{it}^{4.15}$. The hypothesis accepts that a somatic theory of generation of receptor diversity is correct and proposes that self$\mathrm{H}-2$ antigens drive the diversity. Immature $\mathrm{T}$ cells first express an anti-self-H-2 receptor, lcading to proliferation and to accumulation of $\mathrm{V}$ gene mutations until there is no significant reaction with self- $\mathrm{H}-2$. According to this hypothesis, the receptor repertoire of $\mathrm{A}$ strain $T$ cells which had matured in an $A$ environment would be quite different from that of $A$ strain $T$ cells which had matured in a Benvironment. The results presented here are compatible with this hypothesis and with another theory of "adaptive differentiation".

There is an alternative explanation of the results. It may be that the host haplotype preference seen at the level of effector CTL does not reflect a bias in specificity at the level of precursor CTL. The $\mathrm{H}-2^{\mathrm{d}} / \mathrm{H}-2^{\mathrm{b}}$ precursor CTL in the $\mathrm{H}-2^{\mathrm{d}}$ host may have exactly the same range of reactivity as those in the $\mathrm{H}-2^{b}$ host. The haplotype preference of the effector CTL would then be due to the way antigen is presented to CTL precursors. Even though the immunogen (B10 minor antigens) was introduced on $\mathrm{H}-2$ heterozygous cells, the antigen which was responsible for priming CTL may have been processed antigen presented on radiation resistant host cells ${ }^{4}$. In the $\left[\mathrm{F}_{1} \rightarrow \mathrm{C}\right]$ chimaera such radiation-resistant antigen-present-

Table 1 Specificity of $\mathrm{H}-2^{\mathrm{d}} / \mathrm{H}-2^{\mathrm{b}}$ cytotoxic cells from normal and chimaeric mice

\begin{tabular}{|c|c|c|c|c|c|c|}
\hline \multirow[b]{2}{*}{ Responder* } & \multirow[b]{2}{*}{ Immunised with $\dagger$} & \multicolumn{4}{|c|}{ Specific lysis of targets $\ddagger$} & \multirow{2}{*}{$\begin{array}{l}\text { Ratio of lytic } \\
\text { activity on } \$ \\
\text { B10/B10.D2 }\end{array}$} \\
\hline & & $\begin{array}{l}\mathrm{B} 10 \\
\mathrm{H} \cdot 2^{\mathrm{b}}\end{array}$ & $\begin{array}{c}\text { B10.D2 } \\
\mathrm{H} \cdot 2^{d}\end{array}$ & $\begin{array}{c}\mathrm{B} 10 . \overline{\mathrm{BR}} \\
\mathrm{H}-2^{\mathrm{k}}\end{array}$ & $\begin{array}{l}F_{1}(C \times C . B) \\
H-2^{d} / H 2^{b}\end{array}$ & \\
\hline $\begin{array}{l}\text { Experiment } 1 \\
\text { Normal } F_{1}(C \times C . B)\left(H-2^{d} / H-2^{b}\right) \\
\text { Chimaeral }\left[F_{1} \rightarrow C\right] \\
\text { Chimaera }\left[F_{1} \rightarrow C . B\right] \\
\text { Normal } F_{1}(C \times C . B)\end{array}$ & $\begin{array}{l}\mathrm{F}_{1}(\mathrm{~B} 10 \times \mathrm{B} 10 . \mathrm{D} 2)\left(\mathrm{H}-2^{\mathrm{b}} / \mathrm{H} 2^{\mathrm{d}}\right) \\
\mathrm{F}_{1}(\mathrm{~B} 10 \times \mathrm{B} 10 . \mathrm{D} 2)\left(\mathrm{H}-2^{\mathrm{b}} / \mathrm{H}-2^{\mathrm{d}}\right) \\
\mathrm{F}_{1}(\mathrm{~B} 10 \times \mathrm{B} 10 . \mathrm{D} 2)\left(\mathrm{H}-2^{\mathrm{b}} / \mathrm{H} 2^{\mathrm{d}}\right) \\
\mathrm{C}^{\mathrm{d}} \mathrm{H}\left(\mathrm{H}-2^{\mathrm{k}}\right)\end{array}$ & $\begin{array}{r}56.2 \\
19.3 \\
51.8 \\
4.5\end{array}$ & $\begin{array}{r}62.2 \\
72.7 \\
29.1 \\
3.8\end{array}$ & $\begin{array}{r}1.5 \\
2.9 \\
0.1 \\
71.5\end{array}$ & $\begin{array}{l}\text { ND } \\
\text { ND } \\
\text { ND } \\
\text { ND }\end{array}$ & $\begin{array}{l}0.7 \\
0.02 \\
5.2 \\
-\end{array}$ \\
\hline $\begin{array}{l}\text { Experiment } 2 \\
\text { Normal } F_{1}(\mathrm{C} \times \mathrm{C} . \mathrm{B}) \\
\text { Chimacra }\left[\mathrm{F}_{1} \rightarrow \mathrm{C}\right] \\
\text { Chimaera }\left[\mathrm{F}_{1} \rightarrow \mathrm{C} \cdot \mathrm{B}\right]\end{array}$ & $\begin{array}{l}\mathrm{F}_{1}(\mathrm{~B} 10 \times \mathrm{B} 10 . \mathrm{D} 2) \\
\mathrm{F}_{1}(\mathrm{~B} 10 \times \mathrm{B} 10 . \mathrm{D} 2) \\
\mathrm{F}_{1}(\mathrm{~B} 10 \times \mathrm{B} 10 . \mathrm{D} 2)\end{array}$ & $\begin{array}{r}54.8 \\
4.8 \\
61.3\end{array}$ & $\begin{array}{r}68.4 \\
80.5 \\
8.8\end{array}$ & $\begin{array}{l}\text { ND } \\
\text { ND } \\
\text { ND }\end{array}$ & $\begin{array}{l}0.9 \\
1.5 \\
0.1\end{array}$ & $\begin{aligned} & 0.5 \\
< & 0.02 \\
> & 43.0\end{aligned}$ \\
\hline
\end{tabular}

*Chimaeras were prepared as follows: $\mathrm{BALB} / \mathrm{c}\left(\mathrm{C}\left(\mathrm{H}-2^{\mathrm{l}}\right)\right)$ and $\mathrm{BALB} . \mathrm{B}\left(\mathrm{C} . \mathrm{B}\left(\mathrm{H} 2^{\mathrm{b}}\right)\right)$ mice were irradiated with $850 \mathrm{R}$ and reconstituted on the same day with $13.4 \times 10^{6}$ anti-Thy-I plus complement $\left(C^{\prime}\right)$-treated $F_{1}(C \times C . B)$ bone marrow cells. Eight weeks later they were immunised.

†Primed against minor $\mathrm{H}$ antigens by injecting $8 \times 10^{6}$ viable $\mathrm{F}_{1}(\mathrm{~B} 10 \times \mathrm{B} 10 . \mathrm{D} 2)$ splcen cells intrapcritoneally. Splecen cell suspensions were prepared 4 weeks later (experiment 1) or 6 weeks later (experiment 2), and boosted for $5 \mathrm{~d}$ in culture with an equal number of $1,000 \mathrm{R}$ irradiated $\mathrm{F}_{1}(\mathrm{~B} 10 \times \mathrm{B} 10 . \mathrm{D} 2)$ or $\mathrm{C} 3 \mathrm{HebFe} / \mathrm{J}$ spleen cells as described previously ${ }^{11}$

$\$ 2$-d con A (conavalin A) blasts were labelled with ${ }^{31} \mathrm{Cr}$-sodium chromate and used as targets as described previously ${ }^{11}$. Serial dilutions of the killers were assayed against a constant number of targets, and the figures for specificlysis presented here are for a killer: target ratio of $100: 1$. Spontaneous release of ${ }^{51} \mathrm{Cr}$ varied from $18.1-22 \%$ in experiment 1 and from $9.6-13.7 \%$ in experiment 2 .

$\$$ Calculated from the titrations of killers :targets ${ }^{12.13}$. For example. in experiment 1 , the $[\mathrm{F}, \rightarrow \mathrm{C}] \mathrm{cclls}$ lysed B 10 . D2 targets 50 times better than they lysed

$\mathrm{B} 10$ since a $100: 1$ ratio caused $19.3 \%$ specific release from ${ }^{51} \mathrm{Cr}-\mathrm{B} 10$, whereas the same amount of specific lysis of ${ }^{51} \mathrm{Cr}-\mathrm{B} 10$. D 2 was obtained at a ratio of $2: 1$. ND. Not determined. 
Table 2 Sensitivity of chimaera cytotoxic cells to anti-H-2 serum plus C

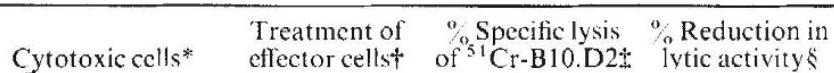

$\left[\mathrm{F}_{1} \rightarrow \mathrm{C}\right]$ anti-

$\mathrm{F}_{1}(\mathrm{~B}|0 \times \mathrm{B}| 0 . \mathrm{D} 2) \quad$ Medium

Normal B 10

serum $+\mathrm{C}^{\prime}$

Anti-H $-2^{b}+\mathrm{C}^{\prime}$

$$
\begin{array}{r}
34.0 \\
34.3 \\
9.8 \\
5.1
\end{array}
$$

Anti-H $2^{\mathrm{d}}+\mathrm{C}^{\prime}$

0
86
94

94

$*\left[\mathrm{~F}_{1} \rightarrow \mathrm{C}\right]$ chimacras were primed in rico 8 weeks after reconstitution. their splecn cells boosted in culture 20 weeks later and assaved for cytotoxicity on day 5 of culture.

$+\mathrm{BALB} / \mathrm{c}$ anti-C57BL/6 and C57BL/6 anti-BALB/c sera were prepared by hyperimmunisation with spleen cells. Effector cells were incubated with mouse sera $1: 2$. washed, and incubated in guinea pig serum $1: 9$ as a source of complement $\left(\mathrm{C}^{\prime}\right)$. Cells were re-suspended to the same volume and assayed.

$\$ C$ on $\mathrm{A}$ blasts from B 10.D2 mice were labelled with ${ }^{51} \mathrm{Cr}$ and used as target. Data presented are for original number of responder spleen cells :target cells of 7:1. Spontaneous release of ${ }^{51} \mathrm{Cr}$ was $20.6^{0} \%$.

$\$$ Calculated from the titrations of killer:targets as in Table 1 .

ing cells would be homozygous $\mathrm{H}-2^{\mathrm{d}}$ and would naturally stimulate only anti-B 10.D2(H-2d $)$ C TL, not anti-B10(H-2b) CTL. Experiments to decide between these interpretations are in progress.

This work was supported by USPHS (grants Al14269 and CA14051).

MiCHAEL J. BEVAN

Center for Cancer Research and Department of Biology,

Massachusetts Institute of Terhnology,

Cambridge, Massachuselts (02139

Received 6 June: acecpted 22 July 1977.

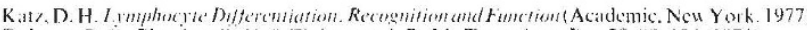
Dolserty. P. C. Blanden. R. V. \& Tinkernagel, R. M. Tramsplam. Ker. 29, 89 124(1976).

Shearer, (i. M.. Rehm, T. (j. \& Schmilt-Verhulst. A. M. Trumsplumt. Rer. 29, 222248 (1976)

Bevan. M. J. Colet Spring Harb. Stmp. quant. Bied. 41, 519 - $527(1976)$.

Blank. K. J J rectmim. H A \& Lilly. F Nature 260,250 $252(1976)$.

Pficenmaier. K etal. J exp. Mct. 143.9991004 (1976)

Zinkernagel. R. M. Nature 261, 139-141 (1976).

von Boehuer. H. \& Hatas. W. Nature 261, 141 142(1976).

Baiky. D. W. Immmogention 2, 249.256 (1975).

Staits. J. Comes Res. 36, $4333.4377(1976)$.

Bevan. M.J. J.eph Med 142.1349 1.365(1975).

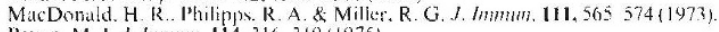

Bevan. M. I. J. Intmith. 114,316 $319(1975)$

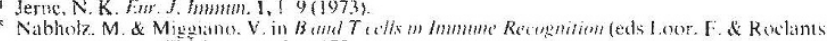
(i. 1.J. Wiles (Chitheser. UK. 1977).

\section{Cytotoxic $\mathrm{T}$ lymphocytes induced in mice by inactivated influenza virus vaccine}

THERE is abundant evidence that $\mathrm{T}$ cell-mediated lysis of virus-infected target cells generally requires $\mathrm{H}-2 \mathrm{~K}$ or $\mathrm{H}-2 \mathrm{D}$ region histocompatibility between cytotoxic $\mathrm{T}$ lymphocytes (CTL) and target cells ${ }^{1-6}$. The biological basis of this requirement is still uncertain. Studies using chimaeric mice suggest that $T$ lymphocytes are selectively sensitised by the viral and $\mathrm{H}-2$ antigens expressed on the infected cell and that killing only occurs when the target cell shares $\mathrm{H}-2 \mathrm{~K}$ or $\mathrm{H}-2 \mathrm{D}$ identity with the immunising virus-infected cell ${ }^{7}$. It is important to determine whether virus infection of the host tissue is, in fact, necessary for specific CTL immunity to develop. If this were so, the use of inactivated virus or purified viral antigens would not be suitable as vaccines against diseases in which CTL were required to afford optimal protection. We report here that inactivated influenza virus vaccines are, in fact, quite capable of evoking haemagglutinin specific CTL.

Epidemiological and experimental evidence indicate that protective immunity against influenza virus is principally directed against the virus haemagglutinin ${ }^{8,9}$. We have recently described the development of haemagglutininspecific CTL in influenza-infected mice ${ }^{10}$. This finding is consistent with these cells playing an important in vivo function in influenza immunity. Our finding contrasts with

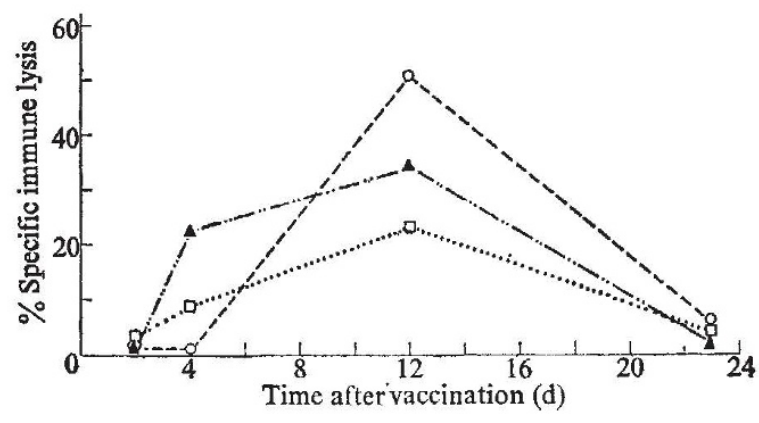

Fig. 1 Specific immune lysis by spleen cells of BALB/c mice immunised intraperitoneally with 5,000 chick cell haemagglutinating units (HAU), (O), $500 \mathrm{HAU}$ (A) and $50 \mathrm{HAU}(\square)$ of A/Port Chalmers formalin-inactivated whole virus influenza vaccine. The spleen cells were tested at a $100: 1$ ratio on A/Port Chalmers-infected syngeneic kidney-derived cells in an 18-h ${ }^{51} \mathrm{C}_{\mathrm{T}}$-release cytotoxicity assay as described previously ${ }^{10}$. The cytotoxic cells generated in vaccine-immunised mice were shown to be $T$ cells by the removal of cytotoxic activity using anti- $\theta$ antiserum plus complement. Thus, whereas untreated splcen cells and spleen cells treated with complement alone achieved 42.3 and $37.0 \%$ specific lysis respectively, spleen cells treated with anti- $\theta$ antiserum plus complement achieved $7.9 \%$ specific lysis, which was not significant $(P>0.5)$.

recent studies which failed to demonstrate haemagglutininspecific CTL in influenza-infected mice ${ }^{11-13}$. These studies differed from our study, however, in the use as target cells of relatively non-permissive influenza-infected transformed cell lines rather than productively-infected normal tissuederived target cells ${ }^{14}$. In the present study we have similarly tested mice inoculated with influenza vaccine, for haemagglutinin-specific CTL reactive with productively-infected target cells. The virus vaccines used contained an early H3N2 virus strain ${ }^{9}, \mathrm{~A} / \mathrm{Aichi} / 68$; a later virus of the same H3N2 subtype, but with a serologically distinguishable haemagglutinin, A/Port Chalmers/73; and an unrelated influenza B virus, B/Hong Kong/72. The target cells were syngencic kidney-derived infected cells ${ }^{10}$. The experiment was carried out in both BALB/c mice $\left(\mathrm{H}-2^{\mathrm{d}}\right)$ and $\mathrm{C} 3 \mathrm{H}$ mice $\left(\mathbf{H}-2^{\mathrm{k}}\right)$.

Figure 1 depicts the CTL response we observed in $\mathrm{BALB} / \mathrm{c}$ mice inoculated intraperitoneally with various doses of A/Port Chalmers vaccine (virus vaccine supplied by Merrell-National Laboratories). Significant cytotoxic Tcell response was observed with each of the doses tested. To determine whether the response was restricted to target cells histocompatible with the immunised mice, we tested spleen cells from $\mathrm{BALB} / \mathrm{C}$ and $\mathrm{C} 3 \mathrm{H}$ immunised mice on syngeneic and allogeneic virus-infected target cells. As indicated in Table 1, the cytotoxic response was detectable only on the syngeneic virus-infected target cells. Specificity of the CTL for the haemagglutinin antigen of the immunising vaccine virus was shown in the experiments recorded in Tablc 2. Thus, CTL-distinguished target cells infected with the immunising strain $\mathrm{H} 3 \mathrm{~N} 2$ influenza virus, from target cells infected with a serologically different but related

Table 1 Virus specificity of cell-mediated lysis by CTL in influenza vaccine immunised micc

\begin{tabular}{lccc}
\hline $\begin{array}{c}\text { Vaccine virus used } \\
\text { as immunogen }\end{array}$ & $\begin{array}{c}\text { Specific immune lysis of target cells* } \\
\text { A/Port Chalmers- } \\
\text { infected }\end{array}$ & $\begin{array}{c}\text { A/Aichi- B/Hong Kong- } \\
\text { infected } \\
\text { infected }\end{array}$ \\
A/Port Chalmers/73 & 96.6 & 6.2 & 8.8 \\
A/Aichi/68 & 5.2 & 67.0 & 2.7 \\
B/Hong Kong/72 & -6.9 & 3.2 & 63.4 \\
\hline
\end{tabular}

*Splenic lymphocytes were tested $8 \mathrm{~d}$ after intraperitoneal immunisation. 